\title{
KOLEKCJA SCHACKA, OGRÓD ARIOSTA I DANTOWSKA OPOŃCZA. WŁOSKA TWÓRCZOŚĆ ADAMA CHMIELOWSKIEGO - PRÓBA INTERPRETACJI
}

„To bardzo wygodnie pod Danta się podszywać, przynajmniej każdy wie, o co idzie" (Schletz 41) - pisał Adam Chmielowski w liście do Lucjana Siemieńskiego, komentując obraz, który właśnie malował, zatytułowany Paolo i Francesca ${ }^{1}$. Ten cytat zdaje się nie być przypadkowy, zwłaszcza gdy zestawimy go z twórczością Chmielowskiego, a dokładnie pięcioma obrazami, o których niżej. Naprowadza nas bowiem na ważny wątek w dorobku malarskim artysty, a mianowicie na nieoczywiste włoskie inspiracje, które są głębsze, niż może się wydawać.

„O Adamie Chmielowskim (Bracie Albercie) pisano dość dużo” - tak zauważał (już w 1939 r.!) Jerzy Sienkiewicz (17). Nie miejsce i czas, żeby wymieniać wszystkie opracowania na temat malarza. Najważniejsze omówiła w 1995 r. Elżbieta Charazińska (41-42), zwracając uwagę przede wszystkim na monografie Franciszka Woltyńskiego, ks. Konstantego Michalskiego i Alicji Okońskiej. Późniejsze prace, już z naszego wieku, to artykuły Marii Gołąb, Aleksandry Krypczyk, ks. Zdzisława Klisia oraz Wacława Pyczka².

Dr JAKUB ZARZYCKI - Uniwersytet Wrocławski, Wydział Nauk Historycznych i Pedagogicznych, Instytut Historii Sztuki, Zakład Historii Sztuki Nowoczesnej; adres do korespondencji: ul. Szewska 36, 50-139 Wrocław; e-mail: jakub.zarzycki@uwr.edu.pl; ORCID: https:// orcid.org/ 0000-0002-4970-5365.

${ }^{1}$ List nie jest datowany, zakłada się, że był pisany w 1870 r. (Schletz 41). Z filologicznego obowiązku trzeba odnotować, że listy Chmielowskiego do Lucjana Siemieńskiego zostały przedrukowane $\mathrm{w}$ trzech publikacjach dotyczących malarza - w pierwszej monografii artysty (Michalski), w opracowaniu materiałów źródłowych związanych z malarzem (Schletz) oraz katalogu Elżbiety Charazińskiej. Cytuję je na podstawie materiałów ks. Schletza, który również wydatował korespondencję artysty, korzystając zresztą z ustaleń ks. Michalskiego.

${ }^{2}$ Ten ostatni został opublikowany w numerze „Zeszytów Naukowych KUL” w znacznej części poświęconemu Adamowi Chmielowskiemu - Bratu Albertowi. W przywoływanym artykule 
Nie sposób nie wspomnieć o monografii Jerzego Malinowskiego z 1987 r. Będę je przywoływał w dalszej części tekstu.

Zasadniczo nie poświęcono jednak większej uwagi temu, jak Włochy, a raczej ich kultura, wpłynęły na twórczość Chmielowskiego. Czy też inaczej - nie postawiono takiej tezy, a następnie nie starano się zweryfikować, na ile tematyka włoska może stać się kolejnym z kluczy interpretacyjnych dla twórczości Chmielowskiego. Dlatego też w niniejszym artykule chciałbym zająć się tą problematyką. Warto zaznaczyć, że pewne intuicje badawcze, związane z nią czy też poszczególnymi obrazami, pojawiały się już wcześniej, ale nie zostały szerzej opisane. Chodzi więc także o zebranie ich w określonym porządku i z pewną myślą przewodnią.

Zajmę się więc analizą dzieł Chmielowskiego oraz kilkoma obrazami Anselma Feuerbacha (i nie tylko). W ten sposób będę chciał rozszerzyć to, co dotychczas wiemy o twórczości Chmielowskiego, starając się udowodnić, że „włoski”, choć nie do końca oczywisty, klucz interpretacyjny jest bardzo ważny w przypadku tego malarza. Najwięcej miejsca poświęcę Sjeście włoskiej, w której rezonuje większość włoskiej tematyki i która niejako streszcza ją w sobie.

\section{MATERIAŁ BADAWCZY}

W sumie możemy mówić o pięciu obrazach (w tym dwóch zaginionych) Chmielowskiego, które są inspirowane Włochami. Biorąc pod uwagę fakt, jak niewiele prac artysty dotrwało do dzisiejszych czasów czy też ile w sumie powstało, liczba ta to i tak sporo, co tym bardziej skłania do zajęcia się tą tematyką ${ }^{3}$. Postaram się więc prześledzić włoskie wątki, bazując na analizie i interpretacji właśnie tego wycinka twórczości.

Do prac tych należą (w kolejności chronologicznej) następujące dzieła ${ }^{4}$ :

badacz zauważał: „literatura przedmiotu dotycząca Adama Chmielowskiego jako malarza jest dość obfita. Dają się zauważyć pewne rozbieżności i kontrowersje dotyczące pozycji artysty w historii polskiego malarstwa. Rzecz wymaga wnikliwego rozpoznania i dokładniejszego opisu" (Pyczek 168).

Można także dodać, że w 2017 r. wydano książkę Natalii Budzyńskiej, przy czym ma ona charakter raczej biograficzno-reportażowy, jej zaś celem była popularyzacja postaci Adama Chmielowskiego - Brata Alberta.

${ }^{3}$ Spośród cytowanych wyżej prac najobszerniejszy i najlepiej opracowany katalog zawiera książka Charazińskiej, dlatego to z niej korzystam w niniejszym artykule.

${ }^{4}$ Dla czytelności niniejszego zestawienia rezygnuję z podawania wykazu prac, w których dane dzieło było wspominane i wszystkie informacje podaję za katalogiem Charazińskiej. 
1. Sjesta włoska (i1. 1), namalowana w 1870 r. w Monachium, olej na płótnie. Inne tytuły: Siesta, Sjesta wtoska, Siesta wieczorna.

Praca zaginiona, znana z fotografii (Charazińska 70) ${ }^{5}$.

2. Francesca i Paolo, malowany przed 1874 r. w Monachium. Obraz zaginiony (Charazińska 72).

3. Ogród miłości (il. 2), 1876 r., olej na płótnie, $88 \times 168 \mathrm{~cm}$, Muzeum Narodowe w Warszawie (Charazińska 53).

4. We Włoszech (il. 3), 1880 r., olej na płótnie, $79 \times 143 \mathrm{~cm}$, Muzeum Narodowe w Krakowie. Inne tytuły: Cmentarzysko, Cmentarz włoski, Krajobraz wtoski, Cmentarz I, Cmentarz wtoski o zmierzchu (Charazińska 56).

5. Szara godzina (il. 4), 1880 r., olej na płótnie, $44 \times 125 \mathrm{~cm}$, Muzeum Narodowe w Krakowie. Inne tytuły Kardynat, Cmentarz II (Charazińska 57).

Szczególnym kontekstem tych rozważań jest sprawa pobytu artysty we Włoszech. Wiemy, że był tam tylko raz - „W 1878 wyjeżdżał na kilka miesięcy do Wenecji" (Czarnocka 323). Charazińska w swoim kalendarium życia i twórczości Chmielowskiego przy Wenecji stawia już znak zapytania (38). Co ciekawe, monografistka artysty, przywołana już Alicja Okońska, która w swojej pracy dosyć szczegółowo opisuje poszczególne etapy życia artysty, pisze: „z końcem r. 1879 zamieszkał Chmielowski z Wyczółkowskim we Lwowie, po powrocie z paromiesięcznego pobytu we Włoszech" (205). Tak więc pobyt Chmielowskiego we Włoszech, który - jak przekonamy się niżej - miał wpływ na jego twórczość, pozostaje zagadką.

Nie są znane szersze wypowiedzi Chmielowskiego na temat Włoch ${ }^{6}$. Właściwie pojawia się tylko jedna uwaga, wyrażona w liście do Siemieńskiego, w której zresztą jest mowa o obrazie Francesca i Paolo:

Cóż Szanownemu Panu o sobie więcej napiszę? Oto chodzę do Akademii znowu i maluję; mam też obraz w robocie parę kochającą się, nic zresztą nowego. Koledzy moi Gierymski Max i Aleksander byli na krótki czas w Wenecji i opowiadają cudowne rzeczy o obrazach, które tam są. Pokazuje się, że z tego, co tu jest, nie można mieć słabego nawet wyobrażenia o Veronese, o Tycjanie i Tintoretto w porównaniu do Wenecji. A jaki kraj ma być przepyszny, jakiego to

\footnotetext{
${ }^{5}$ Pokazywana na wystawie w Towarzystwie Przyjaciół Sztuk Pięknych w Krakowie w 1870 r., wówczas nabyta do rozlosowania, w 1872 r. wylosował ją ks. Ignacy Rybicki z Wierzchosławic (Charazińska 70).

${ }^{6}$ Pozostałe, będące $\mathrm{z}$ reguły jednozdaniowymi uwagami wyrażonymi przy innych okazjach, będę cytował przy opisie poszczególnych prac.
} 
wysiłku imaginacji potrzeba, ażeby zrobić coś zbliżonego do tamtego kraju, jeżeli kto na to mądrym okiem nie patrzał. (Schletz 51$)^{7}$

Dysponujemy zatem raczej szczupłymi materiałami źródłowymi - pozostają więc obrazy.

\section{SJESTA WŁOSKA}

W liście do Lucjana Siemieńskiego z 6 marca 1870 r. Adam Chmielowski tak pisał o Sjeście włoskiej:

muszę to Szanownemu Panu opowiedzieć, że ja też jak każdy inny miewam moje romantyczne godziny, więc mi się zachciało robić Sjestę wieczorna - do tego w starowłoskich kostiumach, mniej więcej z czasów Danta. Nie potrafię robić dużych figur, więc trzeba było się starać, ażeby w całym tonie obrazka było trochę powagi i starości, bez których byłoby to już zupełnie nieznośne. Zrobiłem szkic kolorowy. Mówili mi wszyscy, że nie potrafię zrobić i że nie będzie z czego. Ja jednak wziąłem się do roboty. Kostiumów nie miałem. Więc podług starych rysunków z gałganów rozmaitych kleiłem jak mogłem kostiumy. Nie było męki, której bym nie przeszedł, alem płakał i robił. Już teraz kończę czy dobrze czy źle, nie wiem, ale kończę. (Schletz 29)

Jak wiadomo, obraz został pokazany na wystawie wiosennej w Towarzystwie Przyjaciół Sztuk Pięknych w Krakowie w 1870 r. (Okońska 83), doczekał się również kilku recenzji (84), do których jeszcze powrócę.

Natomiast spośród przeróżnych spostrzeżeń badaczy i badaczek chciałbym odnotować przede wszystkim następujące. Jan Błyskosz pisał: „pod wpływem A. Feuerbacha i A. Böcklina powstała Sjesta włoska (1870), a temat i kompozycja Idylli (1871) uzależnione są wyraźnie od Amarylissa (1866) Böcklina i Ricordo di Tivoli (1868) Feuerbacha" (242). Alicja Okońska, omawiając historię powstawania obrazu, streściła ówczesne głosy krytyki artystycznej oraz wskazała możliwe inspiracje (77-89). Zwracała także uwagę, że obraz „był wyrazem ówczesnych zainteresowań literackich Adama, który rozczytywał się w Dantem, w Boskiej Komedii, znajdując tak bliski swym ideałom wyraz dążeń wolnościowych, a jednocześnie pociągającą jego wyobraźnię twórczą poezję mistyczną i symboliczną" (78). Dalej pisała o możliwych wpływach Veronese i Tycjana, zwłaszcza jeśli chodzi o rozwiązania

${ }^{7}$ Ks. Schletz datuje ten list na ok. 1873 r. (51), Charazińska zaś na czerwiec 1871 (103). Druga data wydaje się bardziej prawdopodobna - w maju 1871 r. bracia Gierymscy byli po raz pierwszy w życiu we Włoszech (Micke-Broniarek 83). 
kolorystyczne (80). Dla Charazińskiej obraz jest dowodem na zainteresowania malarza dawną sztuką włoską $(26)^{8}$.

Wychodząc od tych głosów, chciałbym poruszyć dwie kwestie. Po pierwsze: kim są owe postaci przedstawione na obrazie? Po drugie: czy można wskazać krąg prac czy też tradycję ikonograficzną, z której mógł korzystać Chmielowski?

Przytoczmy głosy krytyki. Antoni Zalewski pisał, że kompozycja przedstawia „coś w rodzaju Dekameronu, grupa figur we florenckich strojach na schodach włoskiej willi” (1).

Lucjan Siemieński:

tu zatrzymuje się kilka poważnych postaci w czerwonych tunikach i zakapturzonych, i zdaje się rozprawia o jakimś ważnym przedmiocie; jedna postać wspaniała i surowa jakby Dantowska; lecz styl rozkoszny szczytu pałacu, i tych galerii, i całego ogrodu wskazuje raczej na późniejsze czasy, jakby na ogrody florenckie Rucellaich, gdzie się lubiły zgromadzać najpierwsze dowcipy na pogadanki przypominające platońskich akademików - gdzie Macchiavelli układał swoje Discorsi, gdzie Policiano, Pik z Mirandoli toczyli literackie spory. Natura tego uroczego, zacisznego miejsca jak i charakter tych purpuratów przechadzających się i rozprawiających, wymownie thumaczy, co to za siestę chciał artysta wystawić - myślą musiał on przenieść się w wiek Medyceuszów i marzyć o tych ludziach, co sławę tego wieku zrobili... Ależ nie tylko same uczone i mądre słowa przynoszą echa tych cienistych platanów i oliwników - tu bliżej nęci naszą ciekawość odmienna grupa: dwie signoryny usiadły na marmurowych wschodach przed nimi, nisko siedzi jakiś młodzieniec - to pewnie kochanek poeta - i czyta z książki, odrywając często wzrok od niej, aby go na której z tych uroczych towarzyszek zawiesić... (2)

Zatrzymajmy się przy tych „czerwonych tunikach” czy też „strojach florenckich" oraz tej ,jednej postaci wspaniałej i surowej jakby Dantowskiej”. Owe stroje były ikonograficznie znane zarówno w średniowieczu i renesansie, jak i w XIX wieku. Nosił je np. Dante i to po niej... został rozpoznany w piekle (Alighieri 219) ${ }^{10}$. Podobny strój ma na sobie także Petrarka z obrazu Böcklina z 1867 r. (il. 5). Czy zatem widzielibyśmy Dantego, czy może jednak jakichś innych florenckich humanistów? $\mathrm{Z}$ trzech powodów skłaniałbym się ku tej pierwszej opcji.

\footnotetext{
${ }^{8}$ O obrazie pisali także m.in. Woltyński (19) i Michalski (144-145).

${ }^{9}$ Tutaj, jak i w kolejnych cytowanych tekstach źródłowych, uwspółcześniono pisownię, zachowując jednak osobliwości zapisu nazw własnych.

${ }^{10}$ Tak opisuje ten strój Porębowicz, wskazując zresztą ikonograficzny prawzór: „to typ szaty florenckiej z kapturem [który] znajduje się na portrecie Dantego pędzla Giotta" (Alighieri 219).
} 
Po pierwsze, Chmielowski - jak czytaliśmy w liście - wprost pisał o „starowłoskich kostiumach, mniej więcej z czasów Danta”.

Po drugie, ważna jest także opinia Okońskiej, czyli owo ,zaczytywanie się" malarza w Boskiej komedii.

Po trzecie, nie bez znaczenia jest tutaj obserwacja Siemieńskiego, który pisał - przypomnijmy - o postaci „surowej jakby Dantowskiej”. Zestawmy to z opisem Dantego, który w 1869 r., czyli rok przed powstaniem Sjesty włoskiej, opublikował Józef Ignacy Kraszewski:

komuż nieznaną jest ta pełna smutnej powagi i zadumy postać, z głową laurem uwieńczoną, a czołem pokrytym myślami - w długiej sukni mniszego kroju zdająca się jakby z grobu zmartwychpowstałą, aby o zagrobowym śpiewać żywocie??

Od pięciuset lat któryż artysta nie próbował jej zeszpecić... a nie potrafił żaden... (...)

$\mathrm{Na}$ wszystkich wizerunkach swych Dante zachował to oblicze surowe wieszcza wygnańca, cierpieniem i geniuszem wzniesionego nad tłumy. Jest to wierne odbicie rysów jego twarzy, bo je Guido da Polenta z umarłego odlać rozkazał, a ten stary odlew (równie jak maska Tassa zachowana w San Onofrio) doszły aż do dni naszych. (120)

Bez większych wątpliwości można więc zakładać, że ikonograficzny typ Dantego, jak wyżej opisany, był obiegową i powszechnie rozpoznawalną formułą ukazywania autora Boskiej komedii, a zatem przyjąć, że to właśnie jego widzimy na obrazie, choć oczywiście ostateczne rozstrzygnięcie przyniosłoby dopiero odnalezienie zaginionego dzieła. Obecność Dantego nie jest tutaj zupełnie oczywista. To nie jemu zostaje poświęcony cały obraz, ale i tak jest w nim ważny, choć nieco skryty pomiędzy innymi postaciami.

Czas zająć się drugą kwestią, czyli wspomnianym już kręgiem prac, którymi mógł inspirować się artysta. Jak wiemy, Chmielowski pozostawał pod wpływem Feuerbacha i Böcklina, a - jak pisałem wyżej - Błyskosz wskazywał nawet, jakie obrazy mogły posłużyć za inspirację $I d y l l i^{11}$.

Zwróćmy jednak uwagę na cytat, który pojawia się w liście do Lucjana Siemieńskiego z 30 stycznia 1870 r., czyli na około dwa miesiące przed powstaniem Sjesty wtoskiej:

nie wiem czy jak Pan był w München, egzystował gabinet Szaka, ale są tam prawdziwe perły. Mnóstwo obrazów Feuerbacha, niektóre śliczne, malowane szaro

${ }^{11} \mathrm{O}$ tych wpływach tak pisał Woltyński: „W układzie, tle, sposobie traktowania pejzażu przypomina żywo wpływy Feuerbachowskie" (19). Ogólne inspiracje Böcklinem zauważał także Nowakowski (88-89). 
bez krzyczących efektów; że jednak mają i surowy styl i wysokie pojęcie przedmiotu, zabijają inne i wszyscy zmuszeni są to przyznać. Są też obrazy Böcklina, w których też ani odrobiny sztuk łamanych, za to jakaś bolesna poezja co za serce chwyta; maluje zwykle greckie rzeczy, nie wypowiada dobitnie myśli a budzi w każdym myśl i marzenie... Niemcy przecie to ogromnie cenią. (Schletz 27-28)

Oczywiście chodzi tutaj o ekspozycję dzieł z kolekcji Adolfa Friedricha Grafa von Schacka, które były pokazywane w Monachium od lat 60. XIX wieku, obecnie zaś są częścią Bayerische Staatsgemäldesammlungen ${ }^{12}$.

Powyższy cytat przywoływali także inni badacze, np. Woltyński (30), Okońska (72) czy Charazińska (26). Aleksandra Krypczyk zwracała uwagę na tę kolekcję, a zwłaszcza na grupę malarzy określanych jako Deutschrömer (11), takich jak Feuerbach, Böcklin i Hans von Marées ${ }^{13}$. Zasadniczo jednak nikt nie podjął wątku poszukiwań tego, jakie to „perły z gabinetu Szaka” mogły być ważnymi źródłami inspiracji dla Chmielowskiego ${ }^{14}$. Wskazałbym zwłaszcza Ogród Ariosta Feuerbacha (il. 6) z 1862 r., od 1863 r. w kolekcji Schacka. Z Chmielowskim łączył go już Malinowski (147), ale bez informacji o tych zbiorach. Malinowski pisał natomiast, że

malarze odwołują się do tej samej epoki. Zbliżone są motywy architektury renesansowej, pejzaż, stroje, lecz wspólny wydaje się przede wszystkim typ nastrojowości. Nawiązanie do sztuki renesansu ma dwojaki aspekt: polega bowiem zarówno na inspiracji malarskimi stylami przeszłości, jak i na pewnym rodzaju estetyzującej idealizacji przedmiotu. (147)

Do tej obserwacji dodajmy kolejną, która wynika zresztą z opinii Siemieńskiego. Jak pamiętamy, zauważał on, że „styl rozkoszny szczytu pałacu, i tych galerii, i całego ogrodu wskazuje raczej na późniejsze czasy”. Oznacza to, że dostrzegano pewnego rodzaju niespójność, polegającą na tym, że bohaterowie obrazu, w tym Dante, byli otoczeni późniejszą architekturą. Można to jednak wytłumaczyć, jeśli zestawimy Sjestę włoska z Ogrodem Ariosta, a następnie zauważmy, że pałac na obrazie Chmielowskiego to

${ }^{12}$ O samym Schacku i jego kolekcji zob. np. Chrambach oraz „Sammlung Schack”. Trzeba zaznaczyć, że zapoznawanie się z kolekcją Schacka w Monachium przez polskich malarzy nie było czymś odosobnionym - pisał o niej np. Stanisław Witkiewicz w Sztuce i krytyce, a dokładnie w rozdziale poświęconym Böcklinowi (524-525). Na marginesie: postulat badań tego typu instytucji jak kolekcja Schacka wysuwała już Halina Stępień (45).

${ }^{13}$ Krypczyk: „udostępnione publiczności zbiory Schacka uchodził wówczas za jedną z najważniejszych i najbardziej oryginalnych kolekcji współczesnej sztuki niemieckiej” (11).

${ }^{14}$ Dodać można, że Okońska łączyła pobyty w tym miejscu z antycznymi zainteresowaniami Chmielowskiego (72). O cytowanym liście do Siemieńskiego, a więc i o galerii Schacka, wspomina też Nowakowski (140). 
zasadniczo trawestacja tego samego motywu z obrazu Feuerbacha. Widzimy niemalże takie same posągi umieszczone w górnych partiach budynku czy też charakterystyczną fontannę na osi pałacu. Chmielowski niejako przesunął całą scenę - umieścił wszystkie postaci na tle, ale i na osi, budynku, podczas gdy Feuerbach oflankował elementami architektonicznymi swoją kompozycję. Na obydwu obrazach występują także postaci w owych florenckich czerwonych sukniach, między nimi zaś toczy się rozmowa.

Te wszystkie zestawienia mogą tylko pozornie wydawać się na wyrost. Nie zapominajmy, że Chmielowski sam pisał, iż ,podług starych rysunków z gałganów rozmaitych kleiłem, jak mogłem".

Następnie zauważyłbym także inny obraz ze zbiorów Schacka, a mianowicie dzieło Ludwiga von Hagna z 1868 r. (i od tego samego roku w kolekcji) pt. Włoska scena ogrodowa (niem. Italienische Gartenszene) (il. 7). Tutaj podobieństwo znów polega na tematyce - oglądamy towarzystwo oddające się intelektualnej rozrywce we włoskiej willi. Widzimy również flankowanie postaci roślinnością oraz fragmentami małej architektury, a także sposób ugrupowania postaci - skupionych wokół jednej czytającej osoby. Tutaj jednak byłbym nieco ostrożniejszy i stawiałbym raczej na wspólnotę tematyki i upodobań estetycznych wokół pewnego rodzaju typu ikonograficznego, czyli właśnie intelektualnej rozrywki w otoczeniu włoskiego krajobrazu.

Przeglądając kolekcję Schacka, trzeba także zauważyć obraz Feuerbacha pt. Laura $w$ kościele (il. 8) z 1865 r. (i od tego roku w zbiorach). W tym wypadku widziałbym inspirację nie tylko strojami - znów florenckie szaty ale i tematyką, czyli sceną z życia Petrarki ${ }^{15}$. Nie chodzi jedynie o spotkanie swojej muzy, ale raczej moment, gdy miłość uwzniośli żywot poety i stanie się bezpośrednim powodem napisania jego dzieła, czyli Canzoniere. Jeśli zaś przyjąć, że taka tematyka, czyli wysokie posłannictwo sztuki czy też intelektualna tematyka dzieła, interesowała Chmielowskiego, to Petrarka, a więc i obraz Feuerbacha, staje się dogodnym wzorem ${ }^{16}$.

Kończąc ten wątek, warto również dodać, że dwa obrazy, o których wspomniał Błyskosz, czyli Amaryliss Böcklina (il. 9) i Ricordo di Tivoli Feuerbach (il. 10) również znajdują się w kolekcji Schacka, co tym bardziej wskazuje na rolę tego zbioru dla artystycznego rozwoju malarza.

\footnotetext{
${ }^{15} \mathrm{Na}$ marginesie można odnotować uwagę Okońskiej: „kostiumy renesansowe czy antyczne pozwalały na barwność kompozycji (czerwone szaty dyskutujących w Sjeście)" (108).

${ }^{16} \mathrm{O}$ zainteresowaniach intelektualnych Chmielowskiego, jak i powszechnym uznaniu, jakie go $\mathrm{z}$ tego powodu otaczało w gronie polskich malarzy, pisano nie raz, np. Charazińska: ,poważany i ceniony za trafność opinii o najnowszej i dawnej sztuce” (38).
} 
Zastanawiający jest jeszcze jeden obraz z tej kolekcji, czyli Idealny pejzaż wiosenny (niem. Ideale Frühlingslandschaft) Arnolda Böcklina, który jednak pochodzi z 1871 r., został więc namalowany po powstaniu Sjesty wtoskiej (il. 11). Podobnie jak u Chmielowskiego, ważna jest w nim sceneria, czyli włoska willa, a także muzykujące czy też przechadzające się postaci. Ponadto zwraca uwagę sam sposób malowania - nieco swobodniejsze kładzenie farby, jakby malarz chciał bardziej oddać wrażeniowość i nieuchwytność tego dnia, a nie jedynie przedstawić akcję samej sceny. Innymi słowy, pewnego rodzaju nastrój.

W oczywisty sposób łączy się to z inną kwestią, czyli samym sposobem malowania Sjesty włoskiej ${ }^{17}$. Jak pisała Okońska:

lecz ta klasycystyczna niemal przejrzystość kompozycji ma swoją przeciwwagę w tym wszystkim, co w środkach malarskich Adama jest typowym romantyzmem: w malowniczości póz, kontrastowej grze światłocienia, zacierającej kształty, w miękkim, mimo pewnej nieporadności warsztatowej, modelunku, a prawdopodobniej również w żywym i ciepłym kolorycie. Obraz pełen monachijskiego „Stimmungu”. (84)

Możemy więc zakładać, że choć tematycznie obraz był bliższy Feuerbachowi, to jednak formalne wpływy Böcklina też były ważne.

\section{FRANCESCA I PAOLO}

Około 1874 r. powstaje kolejny obraz, czyli Francesca i Paolo, inspirowany Boska komedia, a dokładnie Pieśnia V z Czyśćca (Alighieri 49-53) ${ }^{18}$. Znów pojawia się tutaj wątek Dantowski - tym razem w bardzo oczywisty sposób, gdyż obraz jest ilustracją sceny z dzieła florenckiego poety. Do niego także odnosi się przywoływany na początku tego artykułu cytat.

Co ważne, w tym wypadku również powraca wątek kolekcji Schacka. Od 1864 r. znajdował się w niej obraz Feuerbacha pod tytułem... Paolo i Francesca (il. 12). Możemy więc założyć, że Chmielowski nie tylko znał ten obraz, ale zapewne pozostawał też pod jego wpływem.

Niestety nie dysponujemy żadną reprodukcją, dzięki której moglibyśmy ocenić, na czym polegała inspiracja artysty. Warto natomiast zauważyć, że

\footnotetext{
${ }^{17}$ Jak wiemy, wywołała ona rozbieżne opinie i polemiki, w których zagadnienie treści zeszło właściwie na dalszy plan (Charazińska 100-111).

${ }^{18}$ O tymże obrazie, do którego właściwie nie ma materiałów źródłowych, pisała np. Okońska (99-100).
} 
pomimo popularności tego motywu w literaturze polskiej (Marinelli 129), znalezienie obrazów o tej tematyce nastręcza trudność. Odnotować tu można tylko trzy prace.

W 1868 r. w Warszawie Ignacy Lasocki pokazał obraz Franciszka z Rimini (Wiercińska 187), natomiast w 1885 r. w salach Towarzystwa Zachęty Sztuk Pięknych można było oglądać obraz Ludwika Wiesiołowskiego pod tym samym tytułem (Wiercińska 404), a następnie w Salonie Krywulta, w 1887 r., pracę pt. Francesca i Paolo, być może tożsamą z tą pierwszą (Płażewska 415).

Do tego można dodać dzieło Edwarda Okunia pt. Francesca z Rimini (il. 13). Obraz jest obecnie zaginiony, ale znamy go z reprodukcji w Tygodniku Illustrowanym z 1917 r., w 1911 r. zaś był pokazywany w Zachęcie (Biernacka 53-55). Rzadkość tego tematu w malarstwie polskim tym bardziej zwraca uwagę na dzieło Chmielowskiego, które jest warte odnotowania w kontekście badań nad inspiracjami Boska komedia w naszej kulturze.

\section{OGRÓD MIŁOŚCI}

\section{O Ogrodzie miłości tak pisała Okońska:}

jeden z najlepszych obrazów Chmielowskiego i największych pod względem formatu płótna (83 na $167 \mathrm{~cm}$ ), został wystawiony w „Zachęcie” w roku ukończenia. Trudno w nim nie zauważyć wyraźnych związków z Sjesta włoska, którą przypomina renesansowymi kostiumami i wizją jakby z Divina commedia Dantego. $(185)^{19}$

Zastanawiające jest, do której sceny z dzieła Dantego obraz mógłby nawiązywać. Dalej badaczka pisze:

Ogród mitości jest obrazem „stimmungowym”, nokturnem, którego akcja odbywa się o zmierzchu, a więc utrzymanym w „tonie” ciemnym. Treść jego - to składanie ofiarnych wieńców na (umieszczonym w centralnej partii obrazu) płonącym ołtarzu miłości, na którym Chmielowski, podobnie jak Böcklin, kładzie napis „Hedone” (Rozkosz). (186)

Jarosław Marek Rymkiewicz, komentując Pieśni XXVIII Czyśćca, zauważył, że ogród, do którego trafia w tym czasie Dante, staje się ogrodem miłości

${ }^{19}$ Ten obraz jest bodaj najczęściej komentowanym przez badaczy. Wymieniam kilkoro dla porządku: Woltyński (22-23), Michalski (15), Charazińska (29), Kliś (43), Pyczek (175). 
zmysłowej (150-151). Podobny wątek dostrzegałbym właśnie u Chmielowskiego. Wybrzmiewa to zwłaszcza, gdy zauważymy pewnego rodzaju odstępstwo malarza od określonego wzorca ikonograficznego, znanego choćby z obrazu Rubensa, jakim jest „ogród miłości” ${ }^{20}$. Ważnym elementem jest w nim np. fontanna, która symbolizuje źródło miłości.

U Chmielowskiego fontanny nie ma, jest za to ołtarz z palącym się ogniem. Odnosiłby się on raczej do namiętności - to do niej nawiązywałby napis „Hedone”, który symbolizowałby cielesny wymiar miłości. Można więc przypuszczać, że $\mathrm{w}$ ten zupełnie nieoczywisty sposób Chmielowski interpretowałby tekst Dantego oraz określoną tradycję ikonograficzną.

Zajmując się Ogrodem miłości, warto zauważyć jeszcze dwie kwestie. Na ostatnim planie znów pojawiają się postaci w czerwonych strojach, które można uznać za owe „suknie florenckie”, przy czym nie jest to raczej Dante. Bohaterowie na pierwszym planie są odziani mniej więcej tak, jak wówczas wyobrażano sobie postaci $\mathrm{z}$ tego czasu. Najlepiej widać to na obrazie Alexandre'a Cabanela pt. Florencki poeta z 1861 r. (il. 14) ${ }^{21}$. Widzimy więc charakterystyczne opończe bez rękawów, które odsłaniają także kolana, czy też spłaszczone czapeczki nasadzone na czubki głów.

Rzecz jasna Chmielowski raczej nie znał tego obrazu (a przynajmniej nie ma na to dowodów), wskazuję raczej, że pewne wzorce ikonograficzne były wówczas mocno rozpowszechnione, co składało się na ogólny trend - istniejący zresztą silnie w Monachium - jakim był renesansyzm (Krypczyk 25) ${ }^{22}$. Jeśli więc możemy w miarę precyzyjne określić tematykę Sjesty włoskiej (skądinąd niewątpliwie przynależną do tego nurtu), to Ogród miłości zawiera w sobie właśnie pewnego rodzaju ogólniejsze cechy renesansyzmu, co zresztą było widać w samym sposobie potraktowania wzorca „ogrodu miłości”.

Warto w tym miejscu przywołać obraz Rzymskie święto majowe (niem. Römisches Maifest), namalowany około 1872 r. (il. 15). Zauważał go już Nowakowski w swojej monografii, wskazując przy tym, że powstał on pod-

${ }^{20} \mathrm{O}$ popularności tego motywu czy też samego obrazu Rubensa może świadczyć opinia Antoniego Blanka, wyrażona w katalogu kolekcji dzieł księcia Michała Radziwiłła przy okazji jej wystawy w Warszawie w 1835 r.: „obraz znany pod nazwiskiem: Ogród miłości Rubensa, wystawiający scenę domowego życia tegoż mistrza. Był to zapewne ulubiony przedmiot jego uczniów, którzy pod jego kierunkiem ten obraz często powtarzali; nie masz galerii, w której by się on nie znajdował; niniejszy przypisują Van Dyckowi, jego uczniowi ulubionemu" (70).

${ }^{21}$ Ten obraz był również reprodukowany w Klosach w 1874 r. jako Dante deklamujący swoje utwory i opatrzony krótkim opisem (Dante deklamujacy 297-298).

${ }^{22} \mathrm{Na}$ polskim gruncie jednym z najbardziej znanych przykładów są oczywiście prace Aleksandra Gierymskiego, o których pisał Juliusz Starzyński (Aleksander Gierymski oraz Od renesansyzmu do impresjonizmu). 
czas monachijskiego okresu Böcklina, czyli w latach 1872-1874 (Nowakowski 40-46). Pokrywają się one $\mathrm{z}$ monachijskim okresem Chmielowskiego, czyli latami 1869-1874 (Charazińska 37-38). Można więc z dużą dozą prawdopodobieństwa zakładać, że autor Sjesty włoskiej mógł zetknąć się z tym dziełem Böcklina w stolicy Bawarii.

W Rzymskim święcie majowym zwraca uwagę tematyka - postaci, tym razem o antycznej proweniencji, zgrupowane w tanecznym korowodzie wokół centralnego punktu kompozycji, jakim jest obiekt kultu. W samej kompozycji bardzo ważne są ubrane na czerwono postaci umieszczone przy krańcach obrazu. Na swój sposób ten opis, jeśli zmienilibyśmy kostiumy z antycznych na renesansowe, pasowałby do Ogrodu miłości.

$\mathrm{Na}$ tym przykładzie widać, jak u Chmielowskiego pewne wątki - choć powracające w większości obrazów - mogły silniej dochodzić do głosu w zależności od danego dzieła. Tutaj mamy więc do czynienia z ważniejszym „wątkiem Böcklinowskim”, gdy „wątek Dantowski” (obecny w bardzo nieoczywisty sposób) schodzi raczej na dalszy plan.

\section{WE WŁOSZECH I SZARA GODZINA}

O obrazach We Wtoszech i Szara godzina, powstałych około 1880 r., napisano całkiem sporo $^{23}$. Przytoczmy kilka opinii.

Ks. Michalski:

$\mathrm{z}$ tego okresu uderzają nas najpierw trzy obrazy: Szara godzina, We Wtoszech i Wizja św. Matgorzaty. Wszystkie trzy powstały niezawodnie pod wpływem podróży do Włoch. Dwa pierwsze obrazy przedstawiają cmentarz raczej z czasów Odrodzenia, aniżeli starożytności: pojawia się w nich ten sam melancholijny nastrój w ekspresji, jaki już znamy z Monachium i Warszawy. (116)

\section{Zdaniem Okońskiej}

choć obraz powstał pod wpływem wspomnień z podróży do Włoch, posiada te same założenia artystyczne, co inne ,stimmungowe" dzieła Chmielowskiego, jest to bowiem nastrojowa pora przedwieczorna, niebo zakrywają ciemne chmury i tylko dwie krwawoczerwone smugi przecinają je nad nieboskłonem. (Okońska 209)

Odnotujmy nieco obszerniejszą opinię Aleksandry Krypczyk:

\footnotetext{
${ }^{23}$ Poza cytowanymi dalej badaczami i badaczkami warto odnotować, że dziełami tymi zajęli się także m.in. Woltyński (30), Charazińska (32), Kliś (44) czy Pyczek (175).
} 
w twórczości Adama Chmielowskiego (np. Ogród miłości, Szara godzina, Cmentarz włoski) [...], pejzaż był nie tylko nośnikiem określonego nastroju, ale i stanowił symbol losu człowieka i jego emocji. Stany natury związane $\mathrm{z}$ porą roku i dnia, a także stałe elementy krajobrazowe, takie jak cmentarz, mogiła, ogród, rzeka, staw, pewne typy architektury oraz roślinności - drzew i kwiatów - powiązane w określony sposób z sylwetką ludzką, zazwyczaj osamotnioną, często odwróconą tyłem do widza, tworzyły krajobraz z kluczem, w którym określona sytuacja pejzażowa była zapisem, symbolem stanu psychicznego twórcy. [...] najczęściej były to nokturny i szare godziny. Wyraźną inspirację stanowiła w tym wypadku twórczość [..] grupy artystów monachijskich skupionych wokół Arnolda Böcklina, tzw. Deutschrömer. Czasami wpływy te łączono z nawiązywaniem do nurtu renesansyzmu, popularnego w monachijskim środowisku artystycznym. (25)

Dalej badaczka zauważała, że na tych obrazach pojawiał się także „efekt gwałtownego kontrastu”, np. „w łunie zachodzącego słońca lub fragmencie stroju" (25).

Powyższe cytaty streszczają najważniejsze kwestie związane z tymi dziełami, czyli problem inspiracji włoską scenerią, wątek renesansowy, rolę nastroju czy inspiracji Böcklinem oraz to, na ile te dzieła są zapisem zmagań artystycznych i duchowych Chmielowskiego.

Obrazy powstawały jednocześnie, były również wspólnie pokazywane. Wiemy też, że nie zostały do końca zrozumiane, czego bodaj najlepszym przykładem była negatywna opinia Sienkiewicza wyrażona na łamach prasy ${ }^{24}$.

Patrząc na te kompozycje, ale także mając w pamięci powyższe ustalenia badaczy, można pokusić się o następującą hipotezę interpretacyjną: postać w czerwonej opończy ogląda scenę przedstawioną na drugim obrazie. Świadczą o tym niektóre z elementów scenerii, ale przede wszystkim fakt, przypomnijmy, że obraz były pokazywane wspólnie.

Idąc dalej, trzeba koniecznie zapytać, kim jest „postać w czerwieni”. Oczywiście można powiedzieć, że to po prostu kontrapunktowy chwyt kolorystyczny, tak trwale obecny w twórczości Böcklina, co było widać choćby w opisywanym wyżej Rzymskim święcie majowym.

Moim zdaniem widzimy Dantego. Przede wszystkim ze względów kostiumologicznych - w oczywisty sposób jest to jego charakterystyczna opończa „florenckiego kroju”. Jak wskazywałem powyżej, Chmielowski był głęboko świadomy jej ikonograficznego znaczenia. Następnie sama postać czy dzieło Dantego pojawia się w twórczości Chmielowskiego nie raz, stając się wręcz powracającym motywem. Postać zagubiona nie tyle pośrodku ciemnego lasu,

\footnotetext{
${ }^{24}$ Zwraca na nią uwagę choćby Charazińska (32). Do tej recenzji jeszcze powrócę.
} 
ale pośród własnego życia, czyli Dante, doskonale koresponduje z tym, co oglądamy na tych dwóch obrazach.

Dodać do tego można jeszcze opinie badaczy, którzy mniej lub bardziej bezpośrednio wskazywali Dantego. Jak pisała Alicja Okońska:

Ze względu na tę postać obraz był nazywany mylnie Kardynatem, chociaż nie jest to kardynał, a jedna $\mathrm{z}$ tych postaci, które powtarzają się w Sjeście wtoskiej i w Ogrodzie milości, postać w czerwonej opończy i kapturze, „Dantowska” jak nazwał ją Siemieński, a więc łącząca w jeden cykl wszystkie te obrazy z czasów renesansu, cykl dzieł o treści symbolicznej, böcklinowskich w inspiracji, a ,stimmungowych" w operowaniu malarskimi środkami. Gdyby odczytywać ich treść w jakimś powiązaniu, byłaby to zapewne własna interpretacja böcklinowskiego Vita somnium breve, a więc radości wieku młodzieńczego (Sjesta), miłości i rozkoszy, którym hołduje wiek dojrzały (Ogród miłości) i samotności tzw. ,jesieni życia" (Szara godzina). $(210)^{25}$

Jerzy Malinowski:

Sjesta wloska tworzy wraz z Szara godzina i Ogrodem mitości cykl pór ludzkiego życia, a więc: radości wieku młodzieńczego (Sjesta włoska), miłości i rozkoszy wieku dojrzałego (Ogród miłości), samotnej starości (Szara godzina). (150)

\section{Dalej badacz zauważa:}

w obrazach tych elementy akademickiego historyzmu (renesansowe stroje kochanków, czerwona „dantowska” opończa mnicha, architektura) przenikają się $\mathrm{z}$ böcklinowską nastrojowością, stwarzając nieokreśloną, mistyczną aurę tajemniczości. (151)

Choć w opiniach Okońskiej i Malinowskiego pojawia się dużo celnych intuicji i rozpoznań, to jednak nie jestem do końca przekonany co do tego, czy Chmielowski przez całe swoje życie malował renesansowy cykl obrazów. Raczej dostrzegałbym pewien wątek, który co jakiś czas się powtarza, nie tyle zatem świadome tworzenie jakiejś całości, ale raczej coś, co powraca, dochodzi do głosu. Myślę, że tym czymś, a właściwie kimś, jest postać i figura Dantego. Okońska wskazywała na Böcklina jako inspirację, ja natomiast chciałbym zauważyć, co było widać w przypadku poprzednich obrazów, że możemy wskazywać na o wiele głębsze związki z Feuerbachem.

Powiedziałbym więc raczej, że mamy do czynienia nie tyle $\mathrm{z}$ „,cyklem renesansowym", na swój sposób nawiązującym do tematyki Böcklina, ale

\footnotetext{
${ }^{25}$ Na marginesie: Siemieńskiemu chodziło o dantowską opończę, ale w Sjeście włoskiej, gdyż o Szarej godzinie nic nie pisał - zmarł trzy lata przed jej namalowaniem.
} 
z grupą prac, która konkretnie czerpie z dzieł tego malarza, a wątkiem spinającym jest właśnie postać Dantego ${ }^{26}$. Innymi słowy, jest to uparte powracanie do tego samego tematu czy też chęć rozwiązania tego samego problemu artystycznego.

\section{WNIOSKI (1): CHMIELOWSKI I WŁOCHY}

W tym miejscu możemy przejść do wniosków, a następnie do zapowiadanej kwestii nowego klucza interpretacyjnego.

Po pierwsze, trzeba podkreślić, że znaczenie konkretnych obrazów z kolekcji Schacka dla dzieł Chmielowskiego jest nie do przecenienia. Ponadto należy zauważyć, że wpływ Feuerbacha w przypadku tych dzieł może być nawet większy niż Böcklina.

Po drugie, bez wątpienia tematyka włoska towarzyszy artyście właściwie przez cały czas, ale koncentruje się on bardziej na literaturze i kulturze tego kraju niż na samej przestrzeni Italii. Chmielowskiego interesował włoski renesans, ale głownie jego intelektualny wymiar czy też związana z nim tradycja postrzegania roli artysty-intelektualisty. Warstwa wizualna nie miała raczej aż takiego znaczenia, czego dowodzi choćby fakt, że prościej wskazać związki ze sztuką jemu współczesną, a więc z konkretnymi dziełami Feuerbacha czy Böcklina niż obrazami dawnych włoskich mistrzów z monachijskiej Pinakoteki. Oczywiście ważnym punktem odniesienia dla tej tematyki jest krąg Deutschrömer.

Szczególne miejsce w tych włoskich fascynacjach zajmuje Dante i Boska komedia. Bez przesady można powiedzieć, że spośród włoskich wątków jest ona najistotniejsza czy też to ona zawiera w sobie wszystkie najważniejsze treści oraz artystyczne zapatrywania. Odwołania czy to do Dantego, czy do Boskiej komedii pojawiają się niemalże we wszystkich dziełach poświęconych tej tematyce.

Po trzecie, włoskie zainteresowania Chmielowskiego należą więc do wyjątkowych na tle innych polskich artystów. Znamienna jest tutaj opinia Henryka Sienkiewicza: „Obraz jego We Włoszech budzi przede wszystkim pytanie: Co we Włoszech?” (3). Ta opinia pokazuje, jak ówczesna krytyka, przyzwyczajona do pewnej określonej konwencji ukazywania Włoch, była... bezradna. Chmielowski zatem, w ogóle osobny na tle innych polskich malarzy, okazał się także osobny, jeśli chodzi o samą Italię.

\footnotetext{
${ }^{26}$ Za wyjątkiem Ogrodu miłości, gdzie ta problematyka jest bardziej skomplikowana.
} 
Ale można też niejako wziąć w obronę Sienkiewicza i inaczej odpowiedzieć na postawione przez niego pytanie: co jest we Włoszech? Okazuje się, że dokładnie to, czego szuka każdy artysta do rozwoju swojej twórczości. Dla Chmielowskiego najważniejsza była kwestia Stimmungu oraz nieoczywistych zainteresowań intelektualnych, które właśnie po pobycie we Włoszech nabrały najdoskonalszego kształtu. Można nawet zadać pytanie: czy wyjazd do Włoch był mu do czegokolwiek potrzebny? Być może wyjazd do Włoch był ważny jedynie (czy też aż) po to, żeby odkryć (czy też potwierdzić) własne wybory artystyczne.

\section{WNIOSKI (2): CHMIELOWSKI I DANTE - PORTE-PAROLE}

Te trzy wnioski to jednak... za mało. Najważniejszym z nich pozostaje ten, który wynika $\mathrm{z}$ nieco szerszej interpretacji dzieł Chmielowskiego oraz jego dyspozycji intelektualnej - i już został zasugerowany. Powróćmy zatem do początku, czyli do sformułowania malarza, który pisał, że „to bardzo wygodnie pod Danta się podszywać, przynajmniej każdy wie, o co idzie"27.

Choć słowo „podszywać” brzmi dwuznacznie, to jednak pozwala zauważyć, że owa fascynacja Dantem jest o wiele głębsza, niż może się wydawać. Dodajmy jeszcze jeden cytat z listu do Siemieńskiego (być może z 1870 lub 1871 r.), który miał wysłać malarzowi różne tytuły książek wartych przeczytania: „kilka tych książek znam dobrze, ale o inne wystaram się i będę czytał. Biblię mam w domu; Danta czytałem, ale i będę jeszcze czytał" (Schletz 42).

Możemy więc napisać: Dante towarzyszył w intelektualnej wędrówce Chmielowskiego (artysty chodzącego własnymi drogami), ale w dyskretny sposób. Pojawiająca się na obrazach Chmielowskiego „postać w opończy” czy też inne nawiązania do Boskiej komedii pozwalają nam sądzić, że Dante stawał się porte-parole samego Chmielowskiego, który w jego losach odczytywał swoje losy. W oczywisty sposób pojawia się to zwłaszcza w momentach, gdy Chmielowski poszukuje i znajduje się w kryzysie, czyli jak Dante, gdy:

W życia wędrówce, na połowie czasu

Obrawszy błędne manowców koleje,

Pośród ciemnego znalazłem się lasu. (Alighieri 29)

${ }^{27}$ Inspiracją przy pracy nad tym artykułem, a zwłaszcza nad tą częścią, był cytowany już artykuł Luigiego Marinellego poświęcony nieoczywistym związkom Dantego z literaturą polską. 
Czy takie sytuacje mają precedencje w polskiej kulturze? Tak - żeby wspomnieć tylko Józefa Ignacego Kraszewskiego. Pisarz w chwili silnego wstrząsu emocjonalnego - gdy fatalnie zakochuje się (mając już prawie 70 lat) i ma mnóstwo rozterek $\mathrm{z}$ tym związanych, i czuje, że aż $\mathrm{z}$ tego powodu „traci z oczu szlak nieomylnej drogi” - maluje Dantego pośród ciemnego lasu ${ }^{28}$.

Czy zatem Dante może zamienić się w Wergiliusza? Nie wiem, ale w przypadku Chmielowskiego pokusiłbym się o odpowiedź twierdzącą. Pytanie to otwiera nowe badania - tym razem poświęcone nieoczywistej obecności Boskiej komedii (a więc nie tylko skupionej wokół samych ilustracji) i jej autora w polskim malarstwie w latach 1861-1914 ${ }^{29}$.

\section{BIBLIOGRAFIA}

Alighieri, Dante. Boska komedja. Tłum. i oprac. Edward Porębowicz. G. Gebethner i sp., 1909. Biernacka, Małgorzata. Literatura - symbol - natura. Twórczość Edwarda Okunia wobec Młodej Polski i symbolizmu europejskiego. Instytut Sztuki Polskiej Akademii Nauk, 2004.

Blank, Antoni. Katalog galeryi obrazow sławnych mistrzów z różnych szkół zebranych przez ś. p. Michata Hieronima xięcia Radziwiłta wojew. wil. teraz w Królikarni pod Warszawa wystawionych. Drukarnia Gazety Warszawskiej, 1835.

Błyskosz, Jan. „Twórczość artystyczna Adama Chmielowskiego”. Biuletyn Historii Sztuki, nr 2 (29), 1967, ss. 242-244.

Budzyńska, Natalia. Brat Albert. Biografia. Znak, 2017.

Charazińska, Elżbieta. Adam Chmielowski - Św. Brat Albert (1845-1916). Katalog wystawy. Wydawnictwo „Czuwajmy”, 1995.

Chrambach, Eva. „Schack Adolf Friedrich Graf v.”. Neue Deutsche Biographie, Bd. 22: RohmerSchinkel, Dunckner\&Humblot, 2005, ss. 492-493.

Czarnocka, Krystyna. „Chmielowski Adam Hilary Bernard”. Stownik artystów polskich i obcych $w$ Polsce działajacych. Malarze, rzeźbiarze, graficy, red. Jolanta Maurin-Białostocka, Hanna Bartnicka-Górska, Janusz Derwojed i in., t. 1: A-C, Zakład Narodowy im. Ossolińskich, 1971, ss. 323-325.

„Dante deklamujący swoje utwory”. Kłosy, nr 462, 1874, ss. 297-298.

Gołąb, Maria. „Ut pictura musica. O wybranych wątkach muzyczności malarstwa w estetyce, krytyce i sztuce polskiej przełomu XIX i XX wieku”. Mikalojus Konstantinas Čiurlionis. Litewski malarz i kompozytor - lietuviu dailininkas ir kompozitorius - a Lithuanian

${ }^{28} \mathrm{O}$ tej historii, powołując się na książkę Antoniego Trepińskiego pt. Romans Kraszewskiego $z$ wiedenka, pisał Nawarecki. Tam także wszystkie informacje na temat tego niezwykle interesującego, choć chyba obecnie zaginionego, obrazu Kraszewskiego.

${ }^{29}$ Można też tę kwestię postawić jeszcze inaczej: nie tyle szukania samego Dantego, jako bohatera w poszczególnych dziełach, ale właśnie nieoczywistych śladów Boskiej komedii w obrazach. 
painter and composer, red. Henryka Olszewska-Jarema i Joanna Szeligowska-Farquhar, Muzeum Śląskie, 2006, ss. 87-106.

Kliś, Zdzisław. „Adam Chmielowski - Święty Brat Albert”. Folia Historica Cracoviensia, nr 1 (15), 2010, ss. 37-54.

Kraszewski, Józef Ignacy. „Dante. Studja nad komedyą Bozką”. Roczniki Towarzystwa Przyjaciót Nauk Poznańskiego, 1869, ss. 120-189.

Malinowski, Jerzy. Imitacje świata. O polskim malarstwie i krytyce artystycznej drugiej połowy XIX wieku. Wydawnictwo Literackie, 1987.

Marinelli, Luigi. „Polski dantyzm między epiką a etyką. Roczniki Humanistyczne, t. 60, z. 1, 2012, ss. 127-163.

Michalski, Konstanty. Brat Albert. W setna rocznice urodzin (1846-1946). Krajowa Centrala „Caritas”, 1946.

Micke-Broniarek, Ewa. „Aleksander Gierymski. Kalendarium życia”. Aleksander Gierymski 1850-1901. Katalog wystawy, red. Zofia Jurkowlaniec, Maja Porajska-Hałka i Małgorzata Jurkiewicz, Muzeum Narodowe w Warszawie, 2014, ss. 80-93.

Nawarecki, Aleksander. „Przez Königshütte. O dwóch dantejskich podróżach Kraszewskiego”. Po Dantem. Wybór materiałów z VIII Konferencji Pracowników Naukowych i Studentów Instytutu Nauk o Literaturze Polskiej UŚ, red. Józef Olejniczak, Górnośląskie Centrum Kultury, 1996, ss. 84-93.

Nowakowski, Andrzej. Arnold Böcklin. Chwała i zapomnienie. Universitas, 1994.

Okońska, Alicja. Adam Chmielowski. Brat Albert. Instytut Wydawniczy Pax, 1967.

Płażewska, Magdalena. „Warszawski Salon Aleksandra Krywulta (1880-1906)”. Rocznik Muzeum Narodowego $w$ Warszawie, nr 10, 1966, ss. 297-422.

Pyczek, Wacław. „Lekcja pejzażu (według) Adama Chmielowskiego - świętego Brata Alberta”. Zeszyty Naukowe KUL, t. 60, nr 2 (242), 2018, ss. 167-180.

Rymkiewicz, Jarosław Marek. Myśli różne o ogrodach. Sic!, 2010.

„Sammlung Schack”. Die Pinakoteken, https://www.pinakothek.de/besuch/sammlung-schack. Dostęp 9.10.2020.

Schletz, Alfons. „Pisma Adama Chmielowskiego (brata Alberta)”. Nasza przeszłość. Studia do dziejów Kościoła i kultury katolickiej w Polsce, t. 21, 1965, ss. 9-221.

Siemieński, Lucjan. „Z wystawy obrazów Towarzystwa Sztuk Pięknych w Krakowie (IV)”. Czas, nr 99, 1.05.1870, ss. 1-2.

Sienkiewicz, Henryk. „Z wystawy Krywulta”. Gazeta Polska, nr 286, 23.12.1880, s. 3.

Sienkiewicz, Jerzy. Adam Chmielowski. Brat Albert (1846-1916). Katalog wystawy. Muzeum Narodowe w Warszawie, 1939.

Starzyński, Juliusz. „Aleksander Gierymski W Altanie - wprowadzenie”. Aleksander Gierymski „W Altanie”. Katalog wystawy. Muzeum Sztuki w Łodzi, 1971, ss. 5-6.

Starzyński, Juliusz. „Od renesansyzmu do impresjonizmu (malarstwo Aleksandra Gierymskiego w latach 1872-1879)". Rocznik Historii Sztuki, t. 2, 1961, ss. 155-208.

Stępień, Halina. Artyści polscy w środowisku monachijskim $w$ latach 1828-1855. Zakład Narodowy im. Ossolińskich, 1990.

Wiercińska, Janina. Katalog prac wystawionych w Towarzystwie Zachęty Sztuk Pięknych w Warszawie w latach 1860-1914. Zakład Narodowy im. Ossolińskich, 1969.

Witkiewicz, Stanisław. Sztuka i krytyka u nas (1884-1898). Towarzystwo Wydawnicze we Lwowie, 1899. 
Woltyński, Franciszek. Adam Chmielowski (brat Albert) jako malarz. Druk W. L. Anczyca i Spółki. Nakładem autora, 1938.

Zalewski, Antoni. „Wystawa sztuk pięknych w Krakowie r. 1870”. Kraj, nr 98, 30.04.1870, ss. 1-2.

\section{KOLEKCJA SCHACKA, OGRÓD ARIOSTA I DANTOWSKA OPOŃCZA. WŁOSKA TWÓRCZOŚĆ ADAMA CHMIELOWSKIEGO - PRÓBA INTERPRETACJI}

Streszczenie

Artykuł stanowi próbę nowego odczytania pięciu dzieł Adama Chmielowskiego (1845-1916), takich jak Sjesta włoska, Francesca i Paolo, Ogród miłości, We Włoszech i Szara godzina. Malarz inspirował się konkretnymi obrazami znajdującymi się w monachijskiej kolekcji Schacka, takimi jak Ogród Ariosta oraz Paolo i Francesca Anselma Feuerbacha. Opierając się na analizach kolejnych dzieł Chmielowskiego, wskazano, że postać Dantego oraz odwołania do Boskiej komedii stanowią klucz interpretacyjny do odczytania tych dzieł. Włoska twórczość Chmielowskiego pozostaje wyjątkowa na tle ówczesnych polskich obrazów o tej tematyce.

Słowa kluczowe: Adam Chmielowski; Dante Alighieri; renesansyzm; Anselm Feuerbach; SchackGalerie; malarstwo polskie w XIX wieku.

\section{SCHACK'S COLLECTION, THE GARDEN OF ARIOSTO, AND DANTE'S MANTLE. ITALIAN WORKS BY ADAM CHMIELOWSKI: AN ATTEMPT AT INTERPRETATION}

\section{Su m m a ry}

This paper aims to read anew five works by Adam Chmielowski (1845-1916): The Italian Siesta, Francesca and Paolo, The Garden of Love, In Italy and The Gray Hour. It has been previously noted that the painter was inspired by specific paintings from Schack's collection in Munich, such as The Garden of Ariosto and Paolo and Francesca, painted by Anselm Feuerbach. Based on an analysis of Chmielowski's later paintings, the author demonstrates that the figure of Dante and the references to the Divine Comedy constitute an interpretative key to the deciphering of these works. Chmielowski's Italian work remains unique against the backdrop of Polish paintings on this subject at that time.

Keywords: Adam Chmielowski; Dante Alighieri; renaissancism; Anselm Feuerbach; SchackGalerie; nineteenth-century Polish painting. 


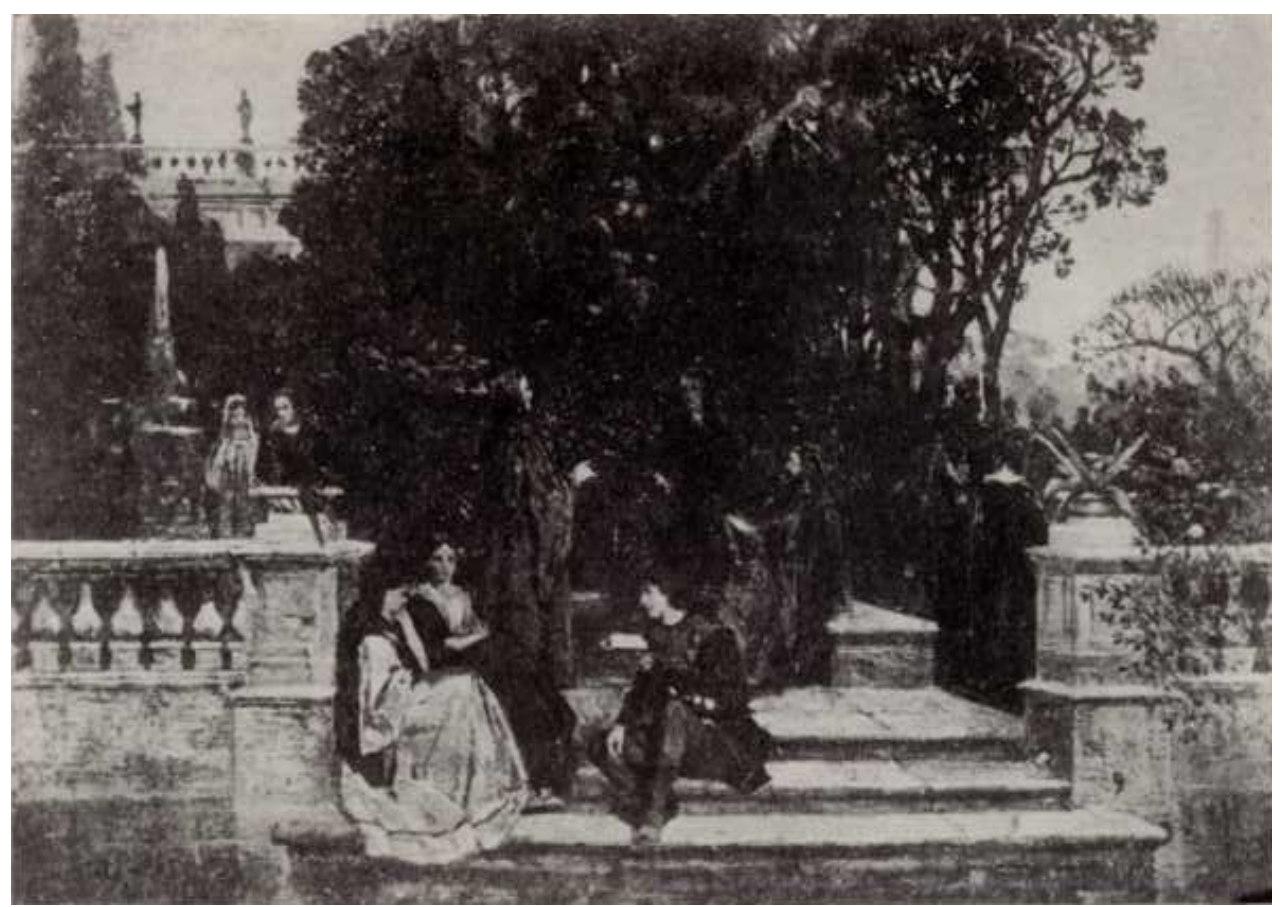

1. Adam Chmielowski, Sjesta włoska, 1870, obraz zaginiony, fot. za: Schletz (po 32)

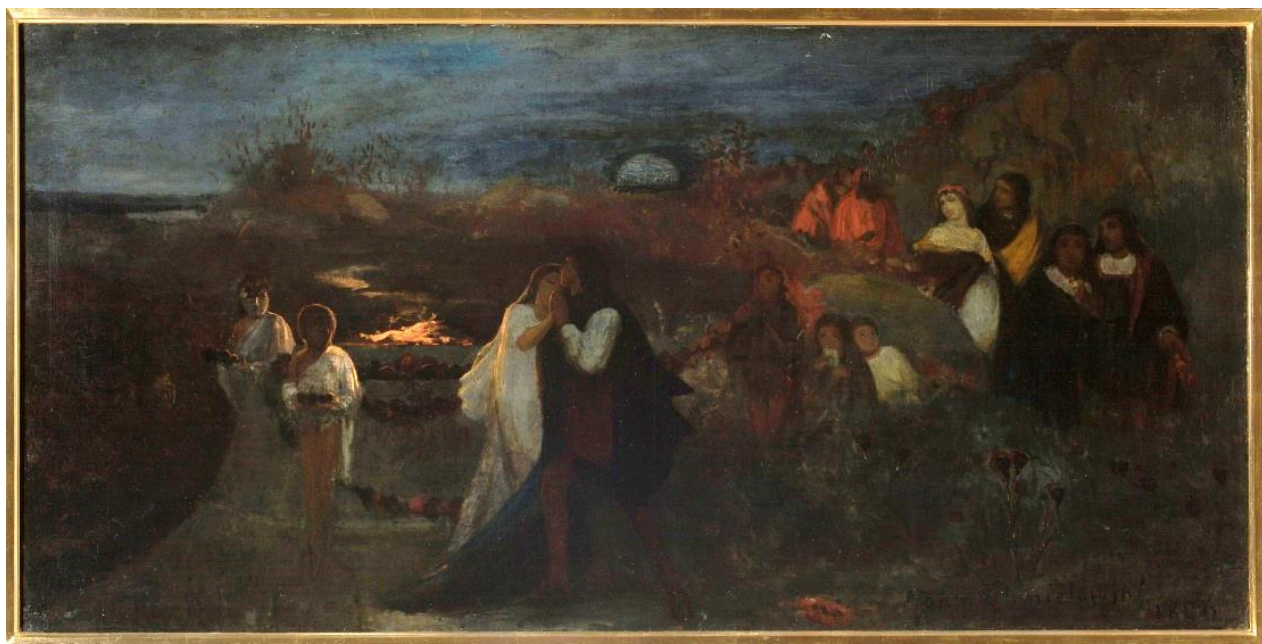

2. Adam Chmielowski, Ogród miłości, 1876, olej na płótnie, $88 \times 168 \mathrm{~cm}$, Muzeum Narodowe w Warszawie,

fot. za: cyfrowe.mnw.art.pl/dmuseion/docmetadata? showContent=true\&id=2868.

Dostęp 9.10.2020 


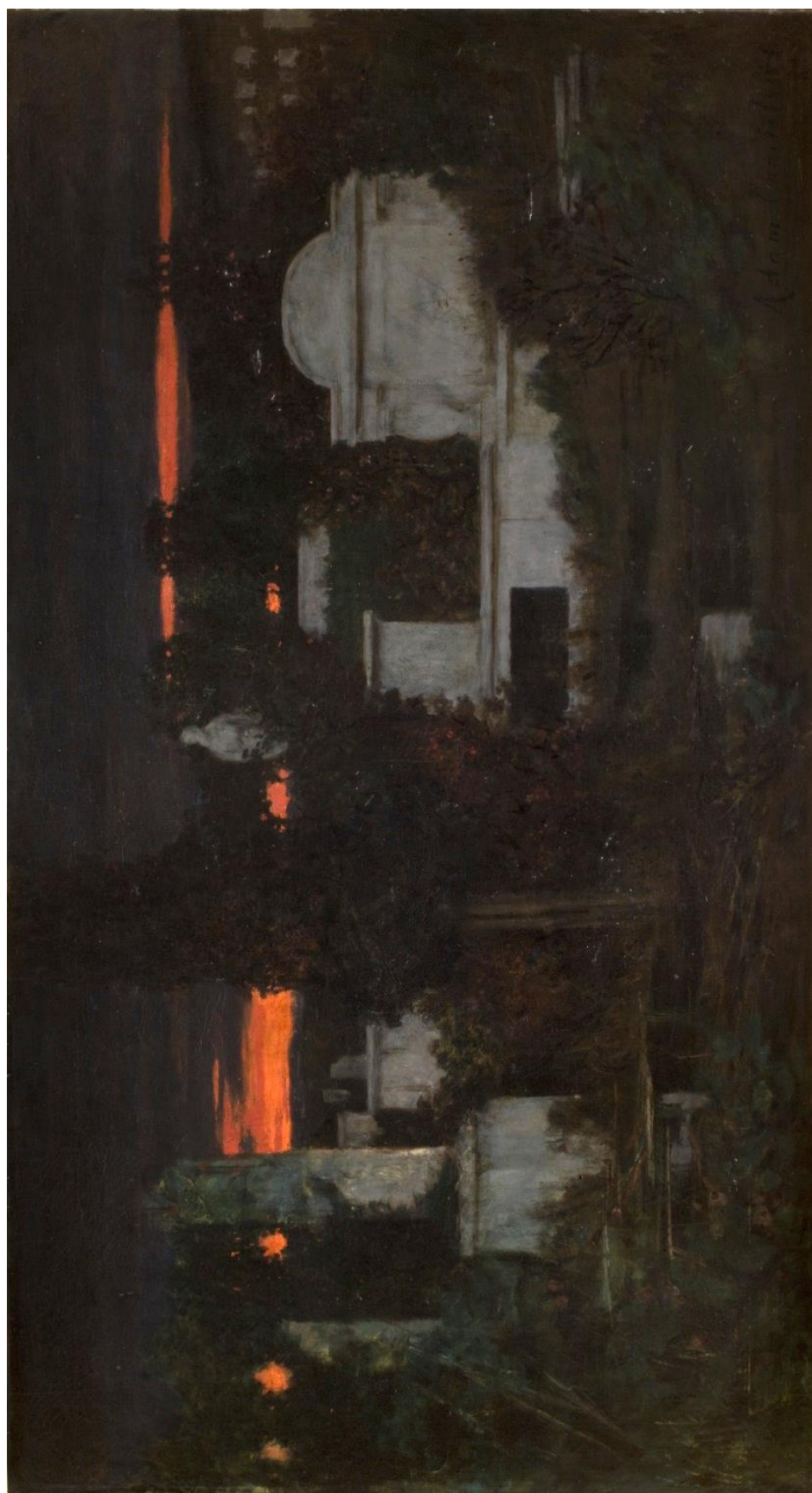

$\frac{0}{3}$
$\frac{0}{\pi}$
$\frac{\pi}{\pi}$

3

๙ิ กิ

음 ำ

을

z

घ बे

ह

$\stackrel{N}{\Xi}$

$\sum n$

ฮี กิ

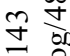

ล

요

.

E

ㅁ. 3

플

बי

은

용

$\infty$

$\leqslant 3$

ड

?

光

$\stackrel{2}{2}$

- $\frac{\bar{v}}{\mathrm{~N}}$

N

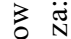

迥

ర

్ㅗㅇ

安

$\dot{m}$ 


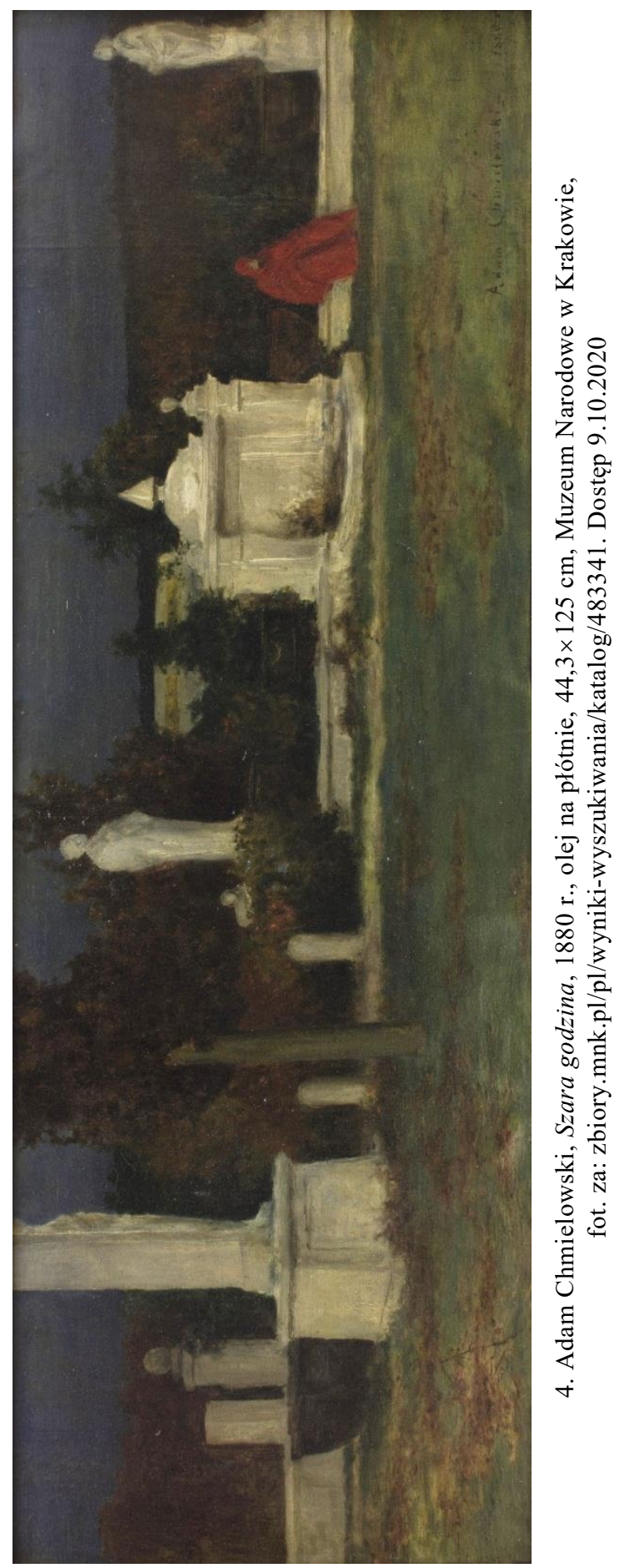




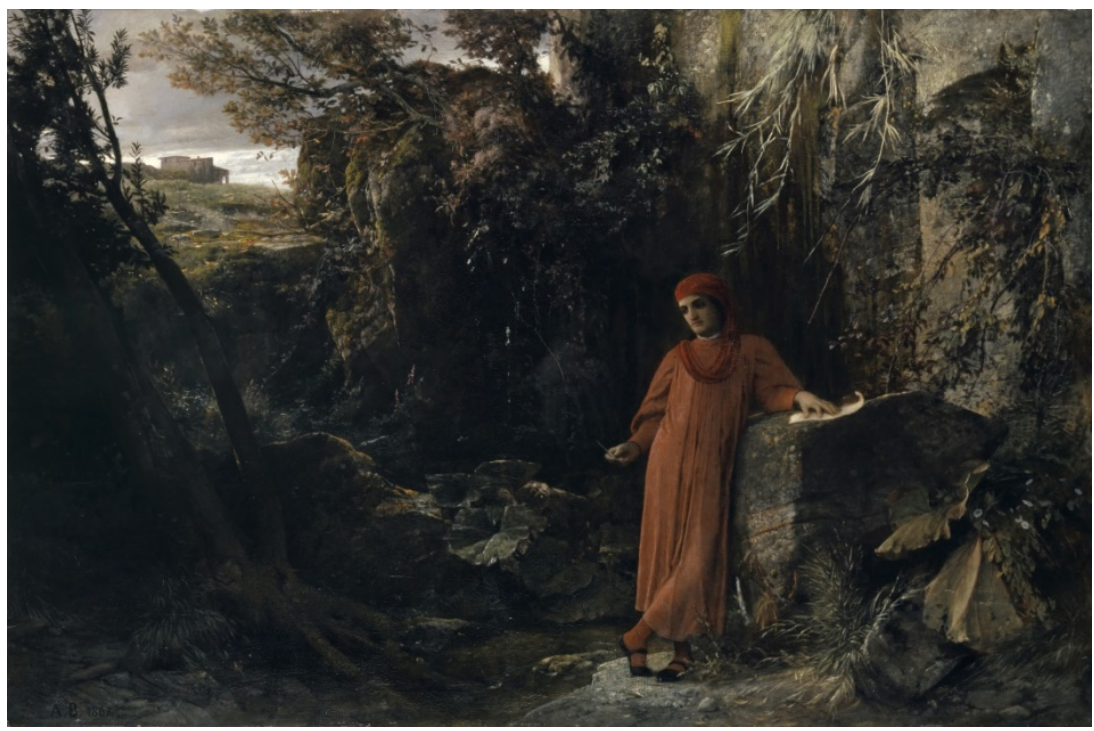

5. Arnold Böcklin, Petrarka przy źródle w Vaucluse [Petrarca an der Quelle von Vaucluse], 1867 r., olej na płótnie, $128 \times 192,5 \mathrm{~cm}$, Kunstmuseum Basel, fot. za:

sammlungonline.kunstmuseumbasel.ch/eMuseumPlus? service $=$ direct $/ 1 /$ ResultDetailView/result.in line.list.t1.collection_list. $\$$ TspTitleImageLink.link\&sp $=13 \& \mathrm{sp}=$ Sartist\&sp=SfilterDefinition\&sp= $0 \& \mathrm{sp}=1 \& \mathrm{sp}=1 \& \mathrm{sp}=\mathrm{SdetailView} \& \mathrm{sp}=121 \& \mathrm{sp}=\mathrm{Sdetai} \& \mathrm{sp}=0 \& \mathrm{sp}=\mathrm{T} \& \mathrm{sp}=0 \& \mathrm{sp}=$ SdetailList $\& \mathrm{sp}=2$ $5 \& \mathrm{sp}=\mathrm{F} \& \mathrm{sp}=$ Scollection $\& \mathrm{sp}=12345$. Dostęp 9.10 .2020

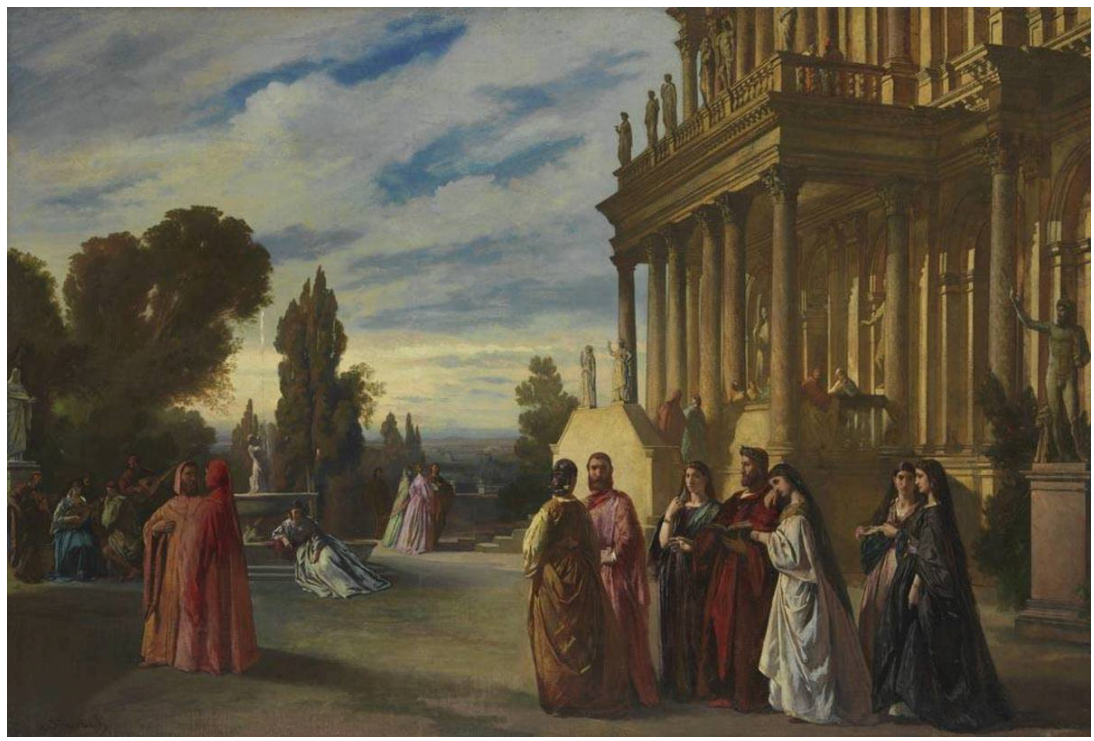

6. Anselm Feuerbach, Ogród Ariosta [Der Garten des Ariost], 1862 r., olej na płótnie, $103,8 \times 154 \mathrm{~cm}$, Sammlung Schack - Bayerische Staatsgemäldesammlungen,

fot. za: www.pinakothek.de/kunst/anselm-feuerbach/der-garten-des-ariost. Dostęp 9.10.2020 


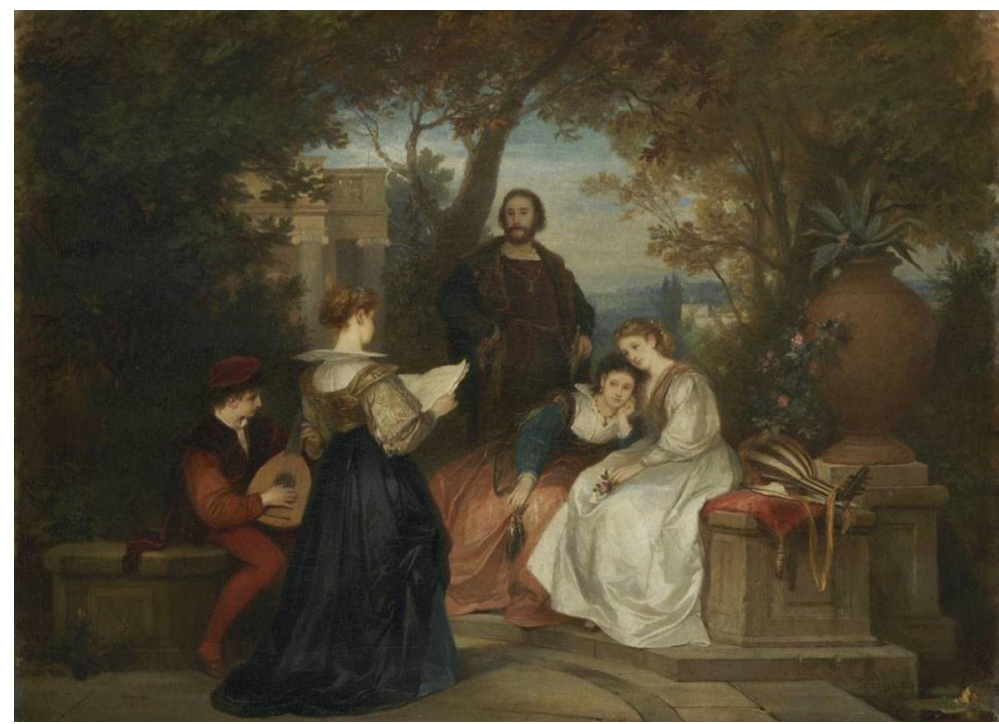

7. Ludwig von Hagn, Włoska scena ogrodowa [Italienische Gartenszene], 1868 r., olej na płótnie, 103,9 x 141,3 cm, Sammlung Schack - Bayerische Staatsgemäldesammlungen, fot. za: www.sammlung.pinakothek.de/de/artwork/y7GE1nvGPV/ludwig-von-hagn/italienischegartenszene. Dostęp 9.10.2020

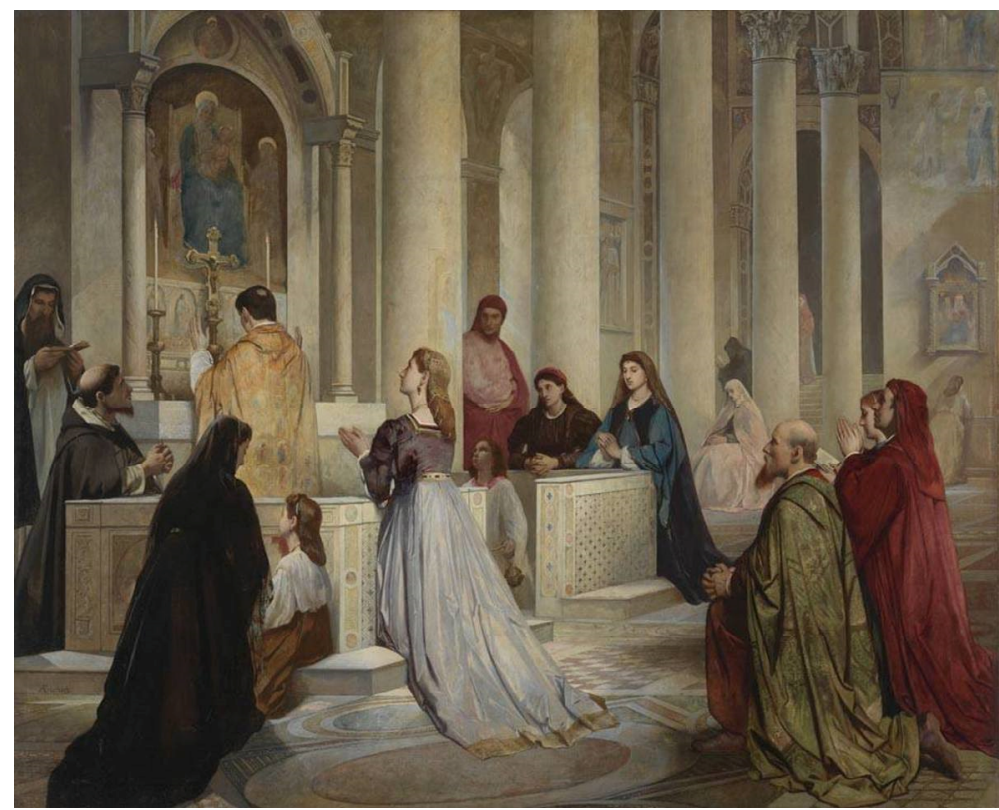

8. Anselm Feuerbach, Laura w kościele [Laura in der Kirche], 1865 r., olej na płótnie, $163 \times 200 \mathrm{~cm}$, Sammlung Schack - Bayerische Staatsgemäldesammlungen, fot. za: www.pinakothek.de/kunst/anselm-feuerbach/laura-der-kirche. Dostęp 9.10.2020 
9. Arnold Böcklin, Amaryliss [Die Klage des Hirten (Amaryllis)], 1866 r., olej na płótnie, $137,9 \times 100,4 \mathrm{~cm}$, Sammlung Schack Bayerische Staatsgemäldesammlungen, fot. za: www.pinakothek.de/kunst/arnoldboecklin/die-klage-des-hirten-amaryllis.

Dostęp 9.10.2020
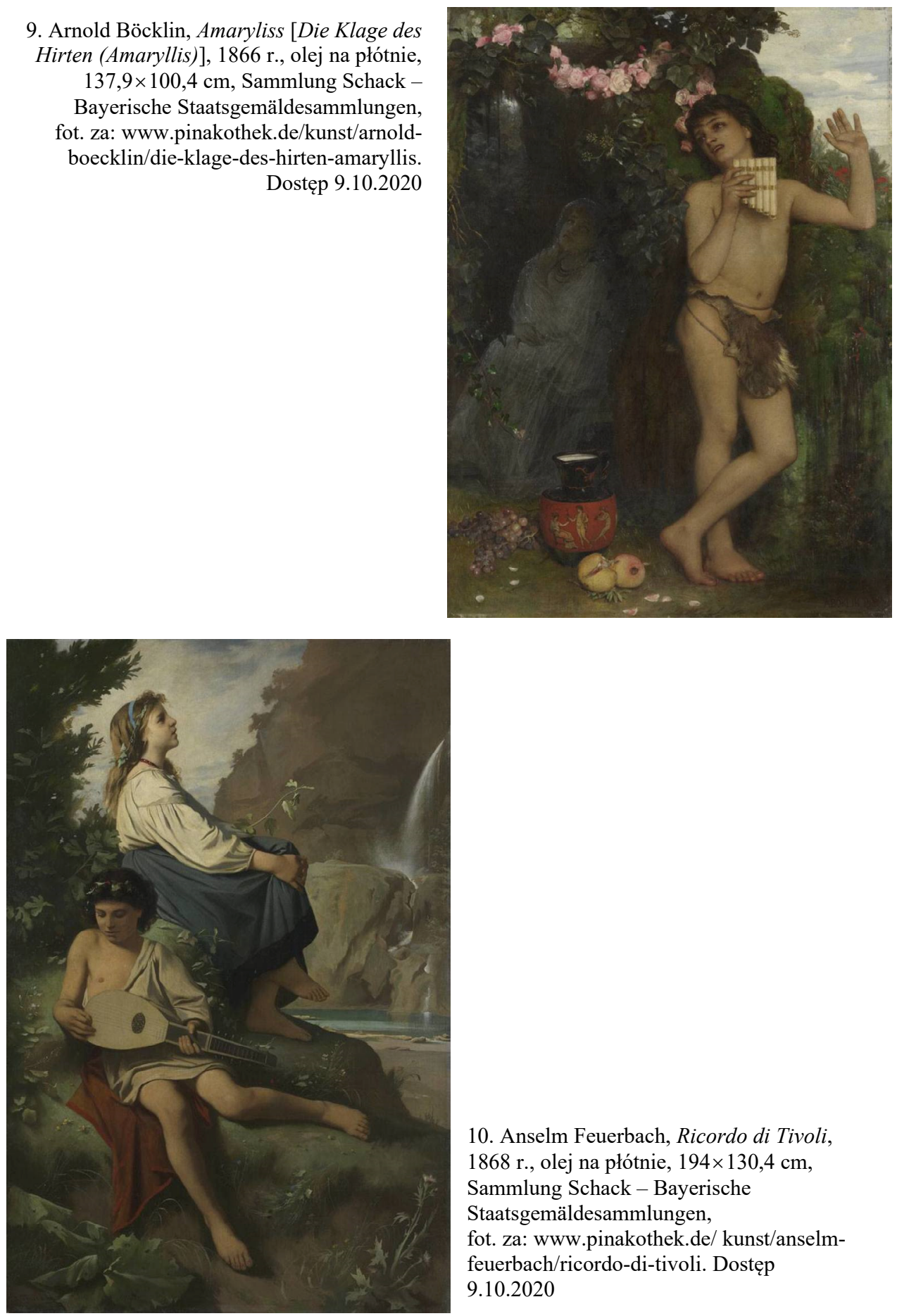

10. Anselm Feuerbach, Ricordo di Tivoli, 1868 r., olej na płótnie, $194 \times 130,4 \mathrm{~cm}$, Sammlung Schack - Bayerische Staatsgemäldesammlungen, fot. za: www.pinakothek.de/ kunst/anselmfeuerbach/ricordo-di-tivoli. Dostęp 9.10.2020 


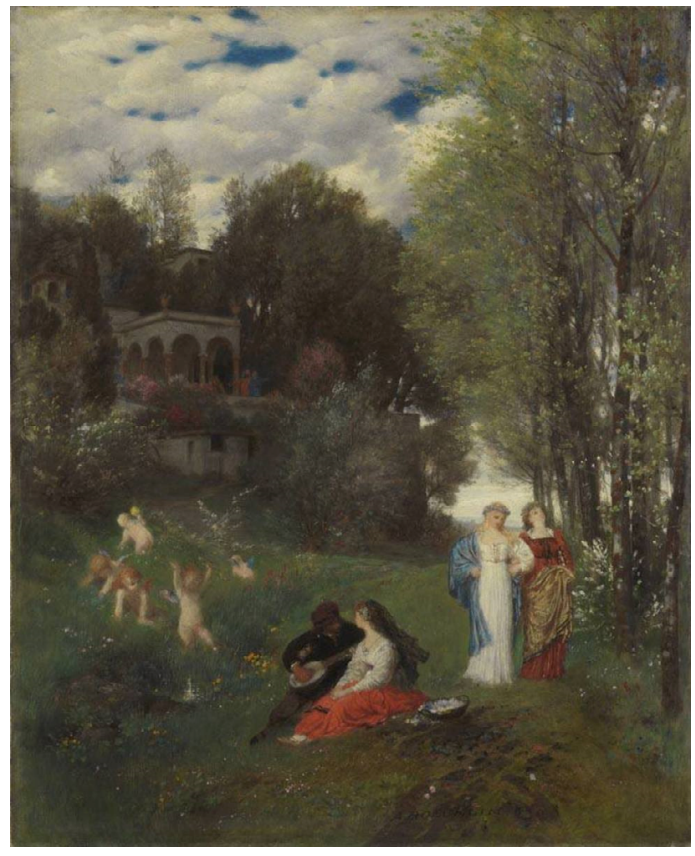

11. Arnold Böcklin, Idealny pejzaż wiosenny [Ideale Frühlingslandschaft], 1871 r., olej na płótnie, $73,5 \times 59,6 \mathrm{~cm}$, Sammlung Schack - Bayerische Staatsgemäldesammlungen, fot. za: www.pinakothek.de/kunst/arnoldboecklin/ideale-fruehlingslandschaft. Dostęp 9.10.2020

12. Anselm Feuerbach, Paolo i Francesca, 1864 r., olej na płótnie, $137 \times 99,5 \mathrm{~cm}$, Sammlung Schack Bayerische Staatsgemäldesammlungen, fot. za: www.pinakothek.de/kunst/ anselm-feuerbach/paolo-undfrancesca. Dostęp 9.10.2020

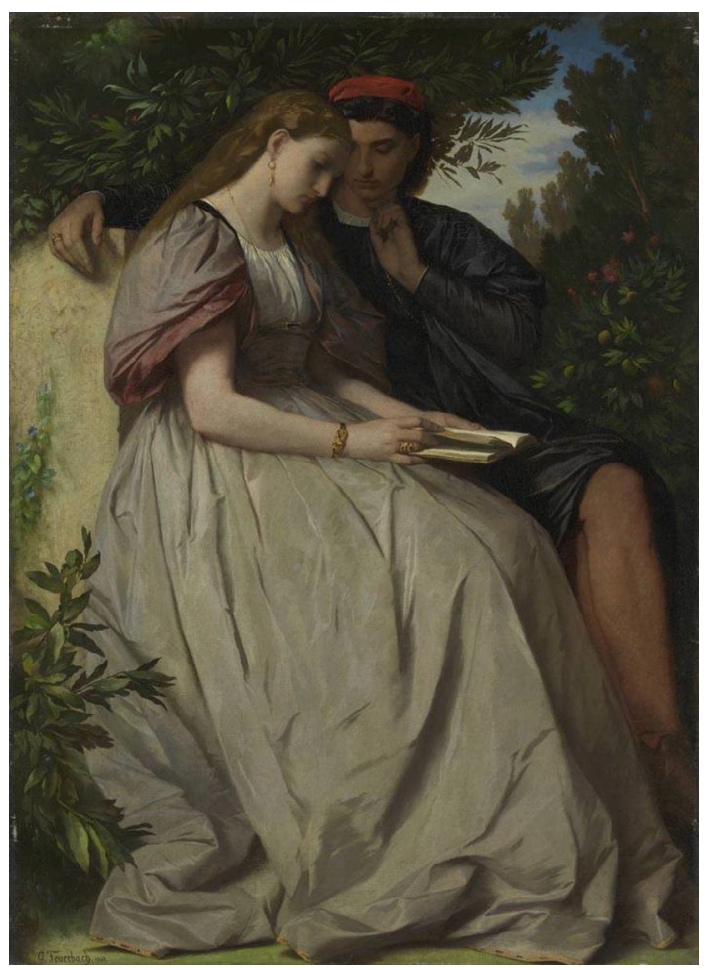




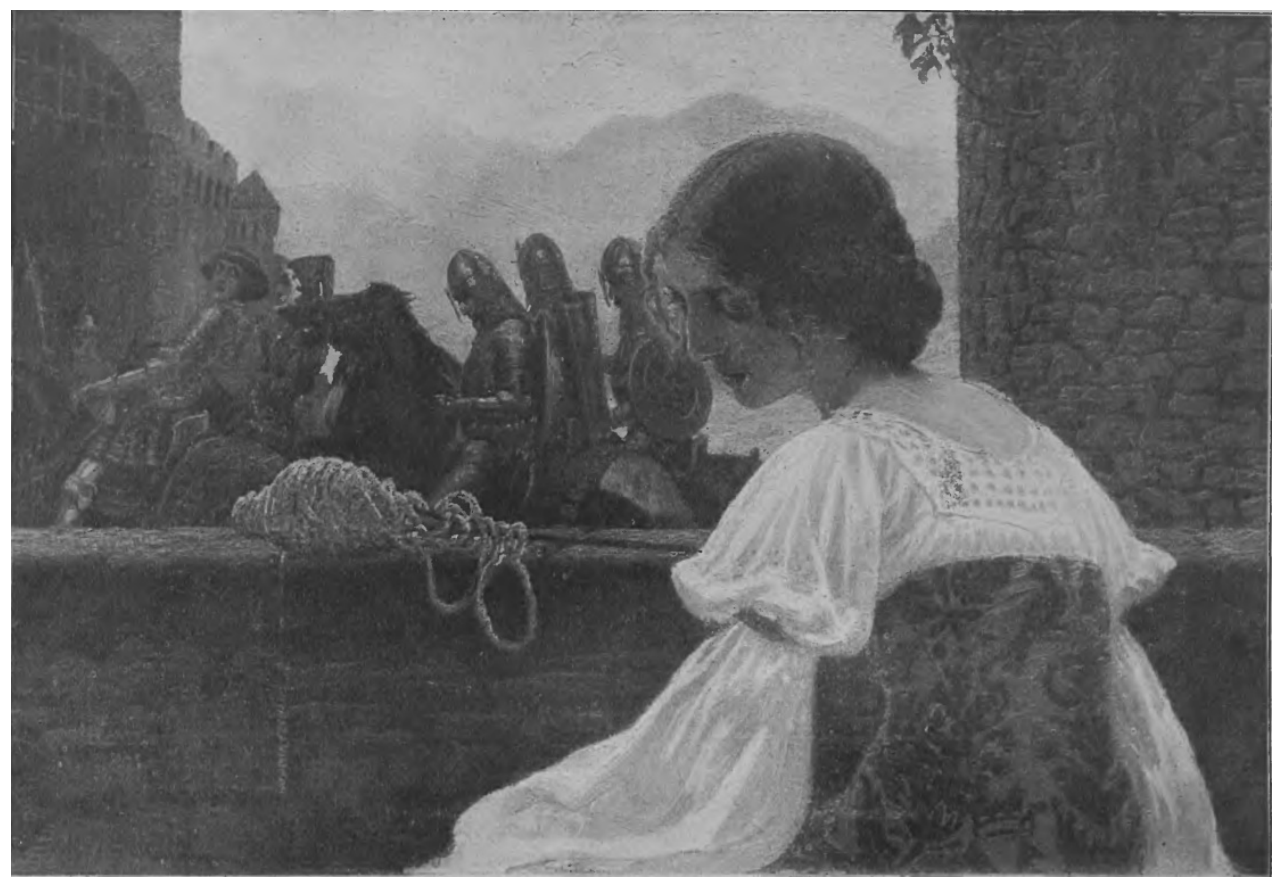

13. Edward Okuń, Francesca z Rimini, za: Tygodnik Illustrowany, nr 48, 1917, s. 587

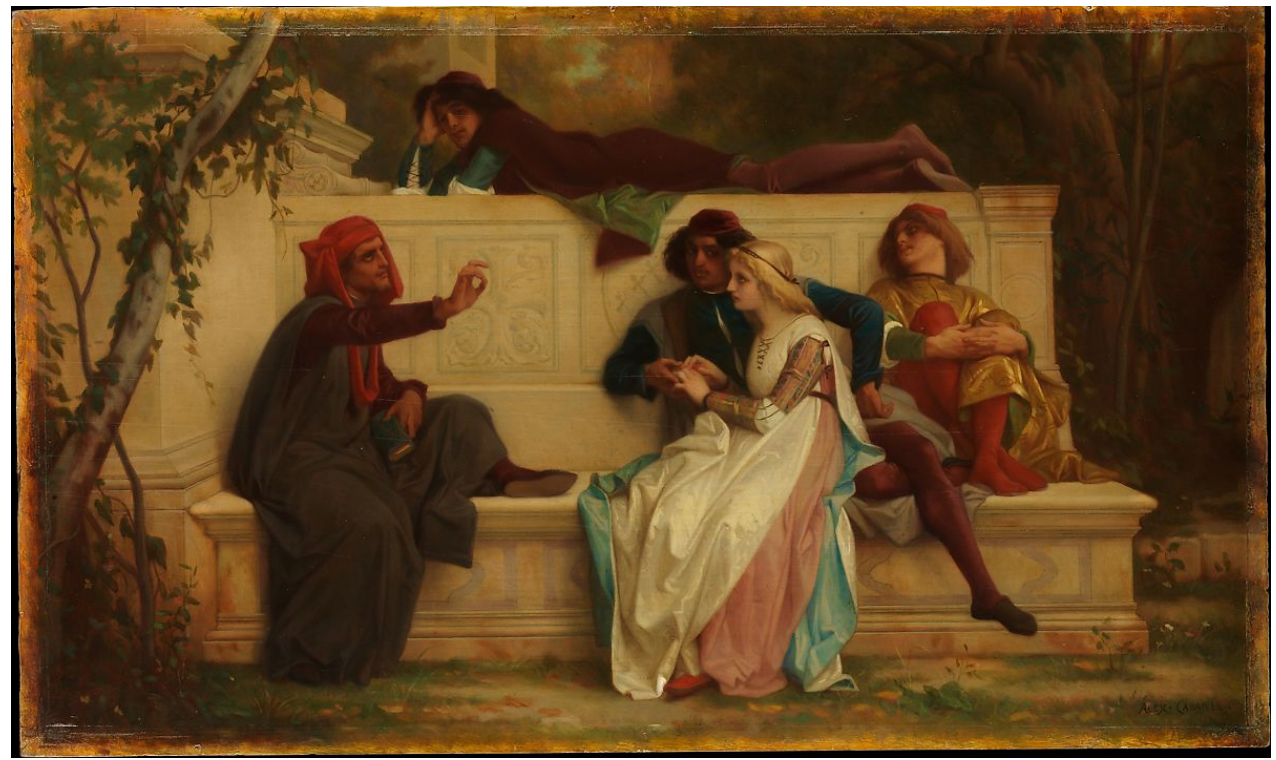

14. Alexandre Cabanel, Florentyński poeta [Florentine Poet], 1861 r., olej na desce, $30,5 \times 50,5 \mathrm{~cm}$, The Metropolitan Museum of Art, fot. za: collectionapi.metmuseum.org/ api/collection/v1/iiif/435832/799836/main-image. Dostęp 9.10.2020 


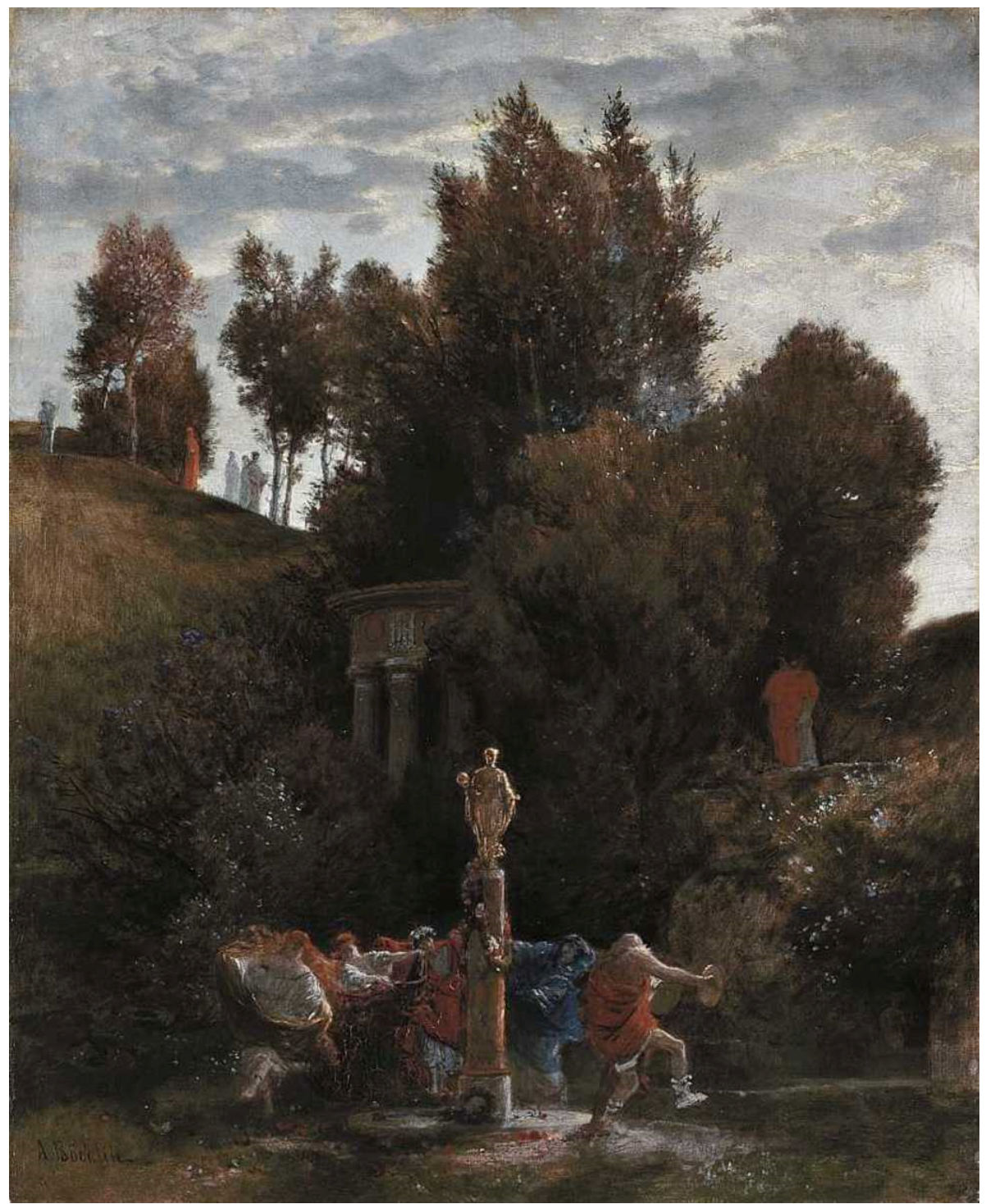

15. Arnold Böcklin, Rzymskie święto majowe [Römisches Maifest], ok. 1872 r., olej na płótnie, $75,5 \times 61 \mathrm{~cm}$, Bayerische Staatsgemäldesammlungen,

fot. za: www.sammlung.pinakothek.de/en/artwork/53470wZx9e. Dostęp 9.10.2020 